\title{
BUNJEVCI U MAĐARSKOJ: POSTMODERNI HETEROGENI IDENTITETI
}

\author{
ESZTER PUNCZMAN \\ Vrhovec 239, \\ HR - 10000 Zagreb, Hrvatska \\ punczmaneszter@gmail.com \\ iD orcid.org/0000-0003-1841-1740
}

Ovaj rad nalazi se u otvorenom pristupu i može se distribuirati u skladu s odredbama licencije CC BY-NC-ND 4.0 HR

Rad se temelji na kvalitativnom etnološkom i kulturno-antropološkom terenskom istraživanju među Bunjevcima u mađarskom dijelu Bačke. Cilj je rada prikazati kako je došlo do poroznih simboličnih granica bunjevačke zajednice i kako su nastali heterogeni identiteti u povijesnom kontekstu kroz tri različite generacije oblikujući bunjevačke identitete. Posljedično, kako se Bunjevci odupiru homogeniziranju u većinu, u nacije, a s druge strane utvrditi heterogeni karakter bunjevačke zajednice u Mađarskoj. Kohezijska sila zajednice više nije bunjevački govor što navodi da etnički identitet ne leži u jeziku, stoga se treba posvetiti onomu zajedničkom među osobama koje se danas smatraju Bunjevcima, što in čini sličnima. Sva imena u radu su pseudonimi, u svrhu zadržavanja anonimnosti kazivača.

Ključne riječi: Bunjevci, hrvatska manjina u Mađarskoj, heterogena kultura, homogena nacija, višestruki identitet

\section{UVODNA RAZMATRANJA}

"Korisnost stranaca i gostiju tako je velika da im se može dati sedmo mjesto po važnosti među kraljevskim uresima... Naime, gosti kad dolaze iz raznih regija i pokrajina, donose sa sobom razne jezike i običaje, razna znanja i oružja. Sve to resi kraljevski dvor, uvećava njegov sjaj i prepada oholost stranih sila. Jer zemlja s jedinstvenim jezikom i običajima slaba je i krhka..." (Anderson 1990:101).

Tim je riječima sveti Stjepan (vladao Mađarskom od 1001. do 1038. godine) savjetovao svoga nasljednika (Anderson 1990:101) sugerirajući da bi se heterogenost trebalo smatrati vrijednošću. S druge strane, potvrđuje da je identitet misao "o drugome 
kao odrazu sebe" u skladu s Bourdieuovim stavom poimanja identiteta, po kojem "identitet leži u razlici (ma kakva ona bila)" (Grbić Jakopović 2014:55). Dakle, identitet stvaramo u zajedništvu s "drugima", u njihovu ogledalu. Ovaj rad analizira jedan od tih bisera mađarske kulture, etničku - manjinsku zajednicu Bunjevaca u mađarskom dijelu Bačke. Cilj je rada prikazati kroz tri različite živuće generacije u povijesnom kontekstu kako se oblikovala etnička simbolična granica od strogih, jasnih do prozirnih, liberalnijih kriterija zajedništva, te kako zajednica preuzima heterogene karakteristike. Cilj je utvrditi heterogene i homogene tendencije kroz analizu načina udruživanja pojedinaca Bunjevaca te kako kazivači razlikuju sebe od drugih sličnih naroda (homogenizacijske tendencije), istodobno se odupirući homogenizacijskim tendencijama većinske nacije (heterogenizacijske tendencije).

Bunjevci su jedna od sedam većih hrvatskih skupina u Mađarskoj: uz gradišćanske, pomurske i podravske Hrvate, te Bošnjake, Šokce i Race. Bunjevci su se doselili u Bačku iz krčko-ličkog i kliškog kraja te hercegovačkog sandžaka od 1607. godine u više migracijskih valova tijekom prodora Osmanlija (Šarić 2014:45). Heterogeni kulturni karakter njihova identiteta javlja se već samom činjenicom da su ugarske vlasti u Podunavlju u 18. stoljeću projicirale dalmatinsko ime na sve doseljenike - prema regionalnom podrijetlu većine doseljenika (Bara 2012:12), stoga će u 19. stoljeću kulturna elita južnougarskih "Dalmatinaca" zbog provođenja preporodnih aktivnosti odabrati ime Bunjevci i tako će postupno dalmatinsko ime u potpunosti biti potisnuto i napušteno (ibid.:22). Kroz stoljeća su se miješali s onima koji tek pristižu u velikim useljeničkim valovima iz područja okupiranih od Osmanlija: Hrvati iz Bosne i Hercegovine i Srbije (Beograd) (ibid.:12). Poslije Drugoga svjetskog rata i deportacija "švapskog stanovništva" (Nijemaca) iz bačkih sela, Bunjevci postaju starosjedioci regije i miješaju se djelomično s Mađarima iz Rumunjske i Slovačke, koji su useljeni u kuće deportiranoga "švapskog" stanovništva, a djelomično sa "švapskim" stanovništvom. Iz povijesnog konteksta nije upitno da je etnički sastav cijele Bačke stoljećima bio vrlo raznolik. Zbog političkih i gospodarskih razloga, danas još ostala prezimena na bačkim grobljima najbolje svjedoče o tome da su tu živjeli različiti narodi i vjeroispovijesti prije mađarizacijskih pokreta. Prema službenim podacima Zavoda za statistiku u Mađarskoj iz 2011. godine, Hrvatima su se izjasnile 26774 (0,3\%) osobe, ${ }^{1}$ a zbog homogenoga, općeg načina u popisivanju stanovništva nemamo podataka o omjeru različitih hrvatskih skupina koje žive u Mađarskoj.

Ova zajednica bila je u fokusu istraživanja znanstvenika i stručnjaka iz raznih područja. U svom istraživanju oslanjam se na autore, znanstvenike, povjesničare i etnologe. Polazište o karakteru bunjevačke zajednice daju Marko Šarić, Robert

\footnotetext{
${ }^{1}$ Središnji ured za statistiku: https://www.ksh.hu/docs/hun/xftp/idoszaki/nepsz2011/nepsz orsz 2011.pdf
} 
Skenderović i Dinko Šokčević u zborniku radova Bunjevci u vremenskom i prostornom kontekstu (2014.) u uredništvu Milane Černelić et al. O seobi i identitetu Bunjevaca koriste se saznanja Marija Bare. Od etnologa i kulturnih antropologa koriste se radovi Jadranke Grbić iz knjiga Multipliciranje zavičaja i domovina (2014.) i Identitet, jezik i razvoj (1994.) te saznanja Milane Černelić i Jadranke Grbić Jakopović o višestrukim identitetima Bunjevaca. Radovi Jasne Čapo Žmegač i Valentine Gulin Zrnić koriste se radi povezivanja identiteta $s$ mjestom življenja. Koriste se saznanja Naile Ceribašić za analizu načina druženja. Knjiga Istvána Fehéra o oslikavanju "zadnjeg trenutka" etničkih manjina u Mađarskoj daje pak podlogu za politički i povijesni kontekst. Terensku građu i osobno iskustvo, budući da sam i sama dijelom iz bunjevačke obitelji iz okolice Baje, analiziram u ozračju sljedeće teorijske pozadine: Eric Hobsbawm (1991) o fenomenu zajednica u postmodernom društvu; o postmodernom shvaćanju identiteta i zajednice koristit ću literaturu Zygmunta Baumana (2001); saznanja mađarskih socijalnih psihologa Györgya Csepelija (2002) i Ferenca Patakija (2001) o oblikovanju identiteta u totalitarnim režimima; Le Bonovu $(1894,2004)$ teoriju o opstanku naroda; teoriju Stuarta Halla (Hall 2003) o hibridnim i mnogostrukim identitetima i simboličnim granicama koje obuhvaćaju identitet (Cohen 1985). Tema o etničkom identitetu nagovještava važnost primordijalističkih i instrumentalističkih perspektiva. Ti su radovi i saznanja dali smjernice za postavljanje pitanja u ovom radu. Inovativnost leži u tome da se radovi spomenutih autora integriraju kroz kvalitativne intervjue baveći se živim iskustvom i subjektivnim elementima identiteta pojedinaca na dva jezika, na mađarskom i hrvatskom (ovisno o kazivaču), u njihovim domovima, na više lokaliteta (od tradicionalnijih sela do liberalnije Budimpešte) kroz tri različite generacije Bunjevaca: najstariji kazivač rodio se 1933., a najmlađi 1997. godine, stoga se podaci odnose na posljednjih 90 godina.

Etnografsko je istraživanje provedeno pomoću utemeljene teorije (Charmaz 2011), etnografskog bilježenja i analize terenskih bilježaka (Emerson et al. 1995). Mrežne stranice koristila sam za utvrđivanje suvremenijih trendova i kulturnih događanja među južnoslavenskim manjinskim skupinama u Mađarskoj. U okviru multilokalnoga terenskog istraživanja (Marcus 1995) putem polustrukturiranih intervjua razgovaralo se s više od 40 kazivača, a u ovom ću radu izdvojiti 33 intervjua, s ciljem promatranja življenja i iskustava među Bunjevcima pripadnicima različitih generacija, obrazovnog statusa i mjesta življenja. Kazivači su birani tako da su svi podrijetlom Bunjevci iz bunjevačkih naselja u mađarskom dijelu Bačke. Od izabranih kazivača 11 in je spontano pristalo na intervju na bunjevačkom govoru, od toga je devetero pripadnika starije generacije, dvoje iz mlađe, dok iz srednje nitko nije na bunjevačkom/hrvatskom razgovarao sa mnom. Od 33 kazivača 23 in je ostalo u svom bunjevačkom selu, 15 imaju visoku stručnu spremu, a ostali srednju ili osnovnu. Po generacijskim razlikama devet je kazivača iz prve generacije (rođeni prije 1945.), 10 in je iz druge (rođeni između 1945. i 1975.), a 
14 iz treće generacije (rođeni poslije 1975. godine). Intervjui na mađarskom prevedeni su na hrvatski jezik, stoga treba uzeti u obzir da neki citati gube na potpunoj autohtonoj jezično-informativnoj vrijednosti.

\section{Utvrđivanje predmeta analize}

Da bih istražila načine udruženja pripadnika bunjevačke zajednice, prvo sam utvrdila na osnovi čega i oko čega se udružuju. Milana Černelić utvrdila je da "Bunjevcima kao etničkoj grupi značajni pokazatelji njihova identiteta su: etničko ime i govor" (Černelić 2005:26), što kod Bunjevaca u Mađarskoj danas nije slučaj. Kohezijska sila istraživane zajednice u Mađarskoj nije toliko bunjevački govor (jer većina Bunjevaca ne koristi ili uopće ne govori taj jezik), nego okupljanje oko narodnog plesa, glazbe, "južnoslavenstva", njegovanja običaja u fragmentima, ali najviše, kolektivno sjećanje kroz koje se ostvaruje doživljaj "kontinuiteta", "neprekidnosti" i "stalnosti" podrijetla, što se podudara sa značenjem riječi "identitet" (Csepeli 2002:516). Elemente doživljaja pripadanja bunjevaštvu koji upućuju na heterogenost a i homogenost, tražila sam u prirodi udruživanja, ponašanja i stavova kazivača Bunjevaca kroz povijesni i politički te zemljopisni i obrazovni kontekst.

Rad se sastoji od tri dijela. Svaki dio ima iste ciljeve definirane na početku rada i analizira isti fenomen u različitom vremenskom i političkom razdoblju: prvi dio bavi se najstarijom, drugi dio srednjom, a treći najmlađom generacijom.

\section{Od bunjevačkih "mijana" do "balkan partyja"}

\section{Prva generacija, rođeni prije 1945. godine}

Od ukupno devet najstarijih kazivača danas in troje nije više među živima. Svaki kazivač naglašava trojezični karakter rodnog sela prije Drugoga svjetskog rata, do deportacije švapskog stanovništva. Svi su se služili trima jezicima: bunjevačkim, "švapskim" i mađarskim. Bez iznimke su se bavili zemljoradnjom, stoga su se družili na "prirodnoj", spontanoj razini na "sokaku", na poljima, dakle na poslu, na klupicama u svakodnevici, u crkvi na misi, u "bunjevačkim krčmama", "mijanama", gdje su svi, koji su odlazili ili dolazili u selo "ajzibanom" (vlak), navratili. Krčme su se razlikovale po etničkoj pripadnost; svaka je narodnost u selu imala svoju krčmu. U nekim selima te krčme zovu mijanama, dok su imućniji imali tzv. kasina, gdje su se gazde sastajale i dogovarale poslove. Mijane su služile za "igranje". Svaku nedjelju bilo je druženje uz glazbu, ples 
jednom tjedno od popodneva do mraka, a u ostale dane to je krčma gdje se kartalo i družilo s ostalim Bunjevcima.

"Pa mijane su trajale dugo, kažem. Bilo in je i 60-ih godina... Mi smo tamo išli uvik igrati, tamo su tamburaši svirali. Ta Lenkina mijana još uvijek postoji, ali sad samo piti idu ljudi tamo kadgod večere držu, ali više nema svirke u mijanama. Nema više, ne sviraju. Do ‘65. - '66. godine znam da su svirali. Onda su još dolazili katymárci svirati... Bila je i garska banda, tamburaška banda, a i katymárci su dolazili svirati, samo sad je to nestalo."

(Ana /Gara/, rođ. 1938., sada pokojna)

Navode jasne "granice" među narodnostima u selu koje se očituju u druženjima i u brakovima iako su se međusobno poštivali, pozdravljali se na ulici s ostalim narodnostima, Švabama, Mađarima, židovima, ponegdje Srbima, i dodaju da danas nije tako. Mladi su se upoznavali na prelima i birali bi svoju buduću suprugu ili muža, ali uvijek u pratnji i uz odobrenje svojih roditelja koji bi onda dogovorili ili odbili mogućnost sklapanja braka. Roditelji su najčešće odobravali brak s Bunjevcem ili Bunjevkom.

"... mi smo se tak upoznali, ona je Bunjevka, ja sam bio Bunjevac, ja sam Bunjevac pravi, i onda smo bili jedan red tako u balu, pa ona je bila sniska, vrtila je tamo malo guzicom pa mi se dopadala i onda sam... i onda je kod nas takva bila moda da morao si pitat, one su, cure su išle s mamama u bal, onda kad si htio da ideš s curom, onda se mora pitat mame, oće dopuštit da mogu ja nju vratit kući, ona je kazala, mama, da može, i onda tako smo, eto, išli kući i tako se upoznali, mi smo se vjenčali '53. godine septembra 26., i od tog doba zajedno živimo, nismo bili rastati ni pol sata, nismo se svadili, nego se posvađamo i pomirimo"

(Stipan /Kaćmar/, rođ. 1933.)

U selima navode kako su mogli biti veliki konflikti zbog miješanog braka, pa je bilo "bježanja" ili se krišom udavalo. U Gari, Kaćmaru, Čikeriji i Čavolju sam uočila najjača uvjerenja o tome kako se miješani brakovi nisu "smjeli" dogoditi u seoskoj zajednici, ta su se tri sela najviše držala homogenima. Navode kako se poslije Drugoga svjetskog rata događalo da se Švabe žene za Bunjevke s ciljem da in ne deportiraju iz Mađarske. Homogena tendencija u sklapanju braka više je dominirala u ruralnim nego u urbanim sredinama, npr. u Baji. Inače, u selima se u to doba svakodnevno čuo bunjevački govor. Prilikom druženja, kako su samo rijetki imali radio, u kućama i krčmama često su kartali, divanili, pjevali, svirali tamburu, harmoniku, "igrali", "pili”, kako oni kažu. Pohađali mise "jer svi su morali ići u crkvu", to je bilo "obavezno" nedjeljom. U Gari navode da se igrala "boća", i to samo Bunjevci, a kasnije generacije to nisu navele, dakle to je posljednji 
trenutak izražaja dalmatinskoga društvenog utjecaja na ovim prostorima u Bačkoj. Selo Gara imalo je jedino ulicu koja se i službeno zvala "Bunjevačka ulica" (i danas je tako). Dakle, u javnom su se prostoru događala svakodnevna bivanja, "hodanje, imenovanje, pričanje, sjećanje". Po De Certeauu tzv. prostorna praksa "prisvajanja prostora sela u svakodnevnom životu" (De Certeau 2003, prema Čapo i Gulin Zrnić 2011:33), to je bio "kulturno značenjski prostor" koji "sadržava iskustvenu, emocionalnu, vrijednosnu, interakcijsku i relacijsku, kognitivnu i senzornu, povijesnu i memorijsku dimenziju" (Čapo i Gulin Zrnić 2011:35). U preferiranoj glazbi pojavljuju se stare bunjevačke narodne pjesme i različite tamburaške pjesme, spominje se Zvonko Bogdan. Ples ne igra središnju ulogu u druženjima. U Gari čak kritiziraju današnju mladež koja dolazi na prela "samo skakat" (misle na 7/8 plesne forme) i "idu u ringišpil", kritički navode da ovi mladi uopće ne razumiju što pjevaju i plešu. Naglašavaju da su u njihovo doba dolazili samo Bunjevci i plesali u parovima, ne kao sada kad "svi" dolaze.

\section{Analiza prvog dijela}

Povjesničar Šokčević navodi da je "veći dio pripadnika tih skupina na mađarskim prostorima čak do sredine 20. stoljeća, posjedovao samo svijest o pripadnosti lokalnoj subetničkoj skupini" jer su od matičnoga hrvatskog korpusa stoljećima izolirana skupina, "ni same nisu rabile za sebe pri samoidentifikaciji etnonim Hrvat", a s "glavnim tijekovima hrvatske nacionalne integracije i razvojem hrvatske nacionalne svijesti nisu imale gotovo nikakve veze, niti su bile integrirane u suvremenu hrvatsku naciju" (Šokčević 2014:89), što se jasno vidi u kazivanjima ove generacije jer su ostali kulturno homogeni u svom seoskom okruženju preko više od 300 godina i posljednja su generacija koja je imala čvrst etnički bunjevački identitet. Do Drugoga svjetskog rata Bunjevci se uspješno odupiru svim nastojanjima heterogenizacije. Po mom iskustvu, najznačajniji povijesni kontekst ove generacije, koji je ubrzao heterogenizaciju pa i asimilaciju Bunjevaca, jest kad se 1948. godine Tito usudio reći ne staljinističkoj politici, pa je postao glavni neprijatelj socijalizma zajedno s cijelom Jugoslavijom, tako i svi Jugoslaveni u Mađarskoj, pa i Bunjevci.

\section{Druga generacija, rođeni između 1945. i 1975. godine}

Srednja generacija socijalizirala se u duhu teorije automatizma, ${ }^{2}$ dakle u političkom kontekstu u kojem je tabu tema narodnosno, etničko, nacionalno pripadanje;

\footnotetext{
${ }^{2}$ Između 1948. i 1960. godine u Mađarskoj i državama Istočne Europe prevladavala je teorija i praksa automatizma, a njezini značajni ostaci nastavili su se sve do sredine 1980-ih, po čemu se pitanje državljanstva rješava samo po sebi, jer će eliminacijom klasnih sukoba biti uklonjeni i temeljni sukobi nacionalnosti. U ovom razdoblju sudbina etničkih manjina u Mađarskoj tragično se promijenila.
} 
javno se ne govori o identitetima, ni o duhovnosti, pa se u većini slučajeva kod ove generacije prekida predaja manjinsko-etničkog jezika i religija gubi na svom značenju u vrijednosnom sustavu društva. Dolazi do naglog porasta miješanih brakova, stižu radio, TV, dakle mediji, migracija iz sela u gradove. Rastu odlasci iz rodnog sela i tako se prekida stoljetnu bunjevačku obiteljsku tradiciju "homogenosti", tradiciju udaje po "čistoj krvnosti", tradiciju zajedničkih kućanstava triju ili više obiteljskih generacija. Među mojim poznanicima i kazivačicama, Bunjevcima iz Budimpešte i okolice, svi su u ovo doba došli u okolicu Budimpešte. U tim miješanim brakovima jezik većine bit će onaj dominantan, dakle mađarski. Komunistički režim u selima zatvara bunjevačke krčme, mijane i kasina, a njihove su vlasnike proglasili kulacima, odveli ih u logore gdje su poginuli ili su na vrijeme pobjegli iz svojih sela i cijele regije, najčešće u Budimpeštu ili u inozemstvo. Često s nostalgijom, spominju kako im nedostaje kad se cijela obitelj okupljala kod bake i djeda, divanilo bunjevački dok se kuhalo u pozadini. Istovremeno, političke sudbine nerijetko razdvajaju tu generaciju. Tipična druženja ove generacije Bunjevaca ovise o tome žive li u gradu, u selu, o sloju kojem pripadaju i kome i čemu su bili vjerni za vrijeme komunizma. Siromašniji su za vrijeme komunizma dobili više mogućnosti školovati se u gradovima i nakon uspješnog školovanja često su i ostali u urbanoj sredini, a većina je Bunjevaca iz siromašnog sloja. Nekoliko se njih vratio u sela, prije svega zbog privrženosti rodbini i zavičaju.

Oni Bunjevci srednje generacije koji žive u većim gradovima, kao što su Pečuh i Budimpešta, imali su mnogo heterogenije okolnosti druženja jer se događa njegovanje bunjevačkog identiteta u institucionaliziranom obliku pod etnonimom "južnoslavenski", od 1948. godine kroz socijalne mreže "srpsko-hrvatskoga" školskog sustava u Budimpešti i u Pečuhu. Tu su školu pohađala djeca svih sedam hrvatskih etničkih skupina u Mađarskoj, uz Srbe, Slovence i djecu iz Jugoslavije koji su iz nekih razloga živjeli u Mađarskoj. Preko toga zajedništva razvile su se kultura i jezik, stoga je heterogeni kulturni karakter utjecao na kulturni identitet Bunjevaca i ukorijenio se u identitet srednje generacije, sad već visokoobrazovanih Bunjevaca. "Jugoslavenski centralni ansambl" osnovan je 1959. godine, kasnije je nazvan "Središnji narodnosni ansambl Luč" i postao je narodni ansambl svih nacionalnih manjina u Mađarskoj: južnih Slavena, Grka, Nijemaca, Rumunja i Slovaka (Lukač 1999) pod vodstvom koreografa Antuna Kričkovića, ${ }^{3}$ Bunjevca iz Gare. Njihovo djelovanje imalo je velik utjecaj na heterogeni kulturni karakter identiteta južnih Slavena u Mađarskoj jer u ime umjetničke slobode Kričkovićeva "koreografija izvire, doduše, u narodnome plesu, ali narodni ples stavlja u službu svoga samostalnog

\footnotetext{
${ }^{3}$ Nekadašnji je plesač ansambla Lado. U mađarskim umjetničkim krugovima zvali su ga samo "Momačko Toni", zbog prve slavne koreografije Momačko kolo. Dobitnik je brojnih plesno-umjetničkih odličja u Mađarskoj.
} 
idejnog sadržaja te je razvilo posebno i prepoznatljivo avangardno plesno kazalište" (ibid.) miješajući i elemente raznih suvremenih plesnih trendova s "tadašnjeg" zapada (plesna tehnika Graham). Unatoč svemu, Kričković navodi u svojoj knjizi da mu nije bio cilj stvoriti "južnoslavenski rezervat", iako je oblikovao plesnu kulturu svih južnih Slavena u Mađarskoj, što potvrđuje kako "Kričkovičevo momačko kolo je plesala cijela zemlja" (Mađarska), kako kaže njegova žena i umjetnička suradnica. Kao odgovor na takvo stvaralaštvo jedan intelektualac Bunjevac iz Baje naziva ga "počiniteljem drevnog grijeha" zbog toga što "je on bio prvi koji je unio makedonske, srbske i tako dalje ritmove i rekoreografiranjem došao do toga da je njegovo momačko kolo postalo jedan svit" u koji je "stavio svakakve elemente, na primjer bubanj, zbog čega to više nije imao veze s momačkim kolom" i dodaje da je najveći problem što je "njegovo djelovanje postala norma među netalentiranim umjetnicima koji onda to smatraju referencom, a to je da možeš srati na sve" (Karlo/Baja/, rođ. 1951.). Na takav način u bunjevačkim krugovima u Bačkoj došlo je do diskursa o sedmoosminskoj glazbenoj mjeri ili ritmu kao "simboličnoj kulturnoj granici" (Cohen 1985) Bunjevaca. Jezgra bunjevačke zajednice distancirala se od takvih "makedonskih ritmova", iako su ti plesovi stekli takvu popularnost da su bili primorani prihvatiti te heterogene trendove:

"Prije, to znam da su kazali da su Bunjevci držali Prela. To je bilo većinom Bunjevački. A sad, sad se radujemo kad dođe nam svaki. Ja ću iskreno kazati, radujemo se, što više njih da dođu. Ne zbog materijalnih stvari, nego zato da vide da još postojimo. Sad se ne igra samo kolo, sad se svakakve igre igraju. Igraju se hrvatske, makedonske, srpske, dakle, svašta. Što volu mladi. Mi moramo za mlade biti ..." (pok. Ana /Gara/, rođ. 1938.)

Danas, 2019. godine, starija i mlađa generacija "Lučaša", svi su suglasni da je plesni ansambl imao jaku snažnu kohezijsku ulogu u životu SHG-a, odnosno Srpskohrvatske gimnazije.

Nakon promjene sistema 1990. godine, mađarski zakon manjinama je dao ustavno pravo stvaranja lokalne i državne samouprave i za vrijeme rata u matičnoj zemlji. Zadatak ove, srednje generacije jest preoblikovanje bunjevačkog identiteta u hrvatski podsustav institucija hrvatskih manjinskih samouprava. Preoblikovanje se ne događa s "bunjevačkog u hrvatski" nego s "bunjevačko-regionalnog i južnoslavenskog" u hrvatski identitet. U psihološkom smislu bila je to stresna i nemoguća misija jer se ni jedan Bunjevac u Mađarskoj nije socijalizirao u "hrvatskom nacionalnom duhu". Kazivači neovisno o generaciji i obrazovnom statusu često navode nametnutnost hrvatstva, jer ga doživljavaju neprirodnim i što nikad "nisu imali posla s hrvatskom nacijom". Odupiranje hrvatstvu kao naciji utvrdila sam u stavovima koji upućuju na regionalni karakter bunjevačkog identiteta, dakle vole udruživanja na jednostavnim, seoskim prirodnim 
prelima (intimnom okruženju); ako bi na popisu stanovništva postojalo "Bunjevac" uz "Hrvat", svi bi kazivači izabrali prvo. Neki su kazivači govor prvog predsjednika Hrvatske doživjeli kao povredu:

"Tuđman kad je bio tu šta je rek'o... Mene je to toliko... Ni ne znam Vam kazat, k'o da me neko ćušio'... 'rek'o: znate što je rješenje toga!? Dođite svi vi u Hrvatsku, mi ćemo vam tamo osigurati stan i radno mjesto. No sad, kakav je to odgovor od jednog predsjednika!? Kad nam je to rek'o, da je to izlaz našeg ovdašnjeg, ne znam ja, iz naših problema, da se odselimo tamo, da će nas oni tamo primit. Da smo se odselili... Mi nećemo tamo biti Hrvati, mi tu 'oćemo biti Hrvati, unutar tog Bunjevci, Raci, Gradišćanci ili ne znam ja, bilo što. Mi tu 'oćemo opstati jer unatrag tristo godina... Zato ni to ne može se zaboraviti, da smo... Naši najbliži preci i ne znam ja su tu pokopani i tu su živjeli, tu su osnovali nov život odande došavši ovamo. I zato nisam tražila državljanstvo, mada sam... Ja sam dobila, i to od Tuđmana, ovaj... odličje hrvatskog pletera" (Ana /Budimpešta/, rođ. 1948., tekst izvorni govor)

Danas, ovi pripadnici srednje generacije sa svojom bunjevačkom zajednicom dolaze u kontakt nekoliko puta godišnje - ako dolaze na programe lokalne hrvatske samouprave - ili nikako. Oni u Budimpešti, s bačkom regijom vrlo rijetko ili uopće nemaju dodira. Neki navode da povremeno posjete rodno selo u Bačkoj nekoliko puta godišnje ili ni toliko. Čim djedovi i bake umru, nemaju zbog čega, koga dolaziti. Neki će njegovati odnos s bačkim zavičajem jedino preko dolazaka na prela u bačka sela, u siječnju ili veljači, kada svakog vikenda mogu odabrati u koje će prelo dolaziti. Prela su do danas najznačajniji događaj bunjevačke zajednice u Mađarskoj. Bačka prela počinju s bunjevačkom himnom "Kolo igra tamburica svira", a ne kao u Subotici gdje je bunjevačka himna "Podvikuje bunjevačka vila". Na prelima bunjevačke i šokačke pjesme dominiraju na početku, pa kažu "onda neki posjetitelji jedva čekaju da ode hrvatski protokol da bi mogli tražiti od orkestra makedonske i srpske pjesme", na što se tad odjednom napuni poluprazan plesni podij. Općenito na glazbenim priredbama najpopularnije su pjesme, na primjer, "U tom Somboru", razne bunjevačke melodije, "Subotičko kolo", "Novi rokoko", "Ej što ću nane", "Zemljo makedonska", "Jovano, Jovanke", "Zelene oči", "Šurda" i slično. Za razliku od bačkih prela, hrvatski bal u Budimpešti ima homogenizacijske tendencije prema hrvatskoj naciji, s hrvatskom himnom na početku, pozvanim orkestrom iz Hrvatske i visokim uzvanicima, gostima iz Hrvatske.

Drugi, popularan način druženja jest dolazak na tzv. Yugo party ili Balkan party u organizaciji različitih ugostiteljskih objekata u Budimpešti, Pečuhu i u Baji više puta godišnje. Organizatori Yugo partyja, Vojvođani, u Budimpešti posljednjih 10 godina dovode 
- "u srcu Mađarske" - velike "legende" ex-yu glazbe na sreću ovdašnje heterogene južnoslavenske manjine: Magazin, Željka Bebeka, Plavi orkestar, Bajagu, Crvenu jabuku, dok u organizaciji Hrvatske samouprave u Pečuh dolaze i popularni bendovi iz Hrvatske, kao što su Učiteljice, Miroslav Škoro, Mejaši itd., čak Marko Perković Thompson.

\section{Analiza drugog dijela}

Autorica Ágnes Tóth navodi u svojoj studiji o deportacijama u prepolovljenoj Bačko-bodroškoj županiji između 1945. i 1948. kako traume i uznemiravanja koje su narodnosti pretrpjele u to doba, desetljećima poslije određuju kvalitetu zajedničkog života svih narodnosti, manjina koje su tu živjele, što je bilo podložno umjetno stvorenim manipulacijskim naporima kojima se nastojalo potaknuti kontradikcije radi postizanja ideoloških ili političkih ciljeva (Tóth 1989). Oblikovanje etničkog identiteta srednje generacije Bunjevaca moramo gledati u kontekstu duha ideologije automatizma jer kod njih dolazi do sustavnog narušavanja etničko-kulturnih simboličkih granica. Staljin i njegovi pratitelji smatrali su uređivanje političkog sustava po klasnom pripadanju višim i efikasnijim od nacionalnoga, stoga su rad nacionalnih/manjinskih saveza ograničili na kulturne aktivnosti (Lásztity 1987:210). Dakle, u ovo je doba greška govoriti o ikakvoj "mađarizaciji" jer, kako Fehér u knjizi Posljednji trenutak, nacionalne manjine u Mađarskoj između 1945. i 1990. navodi, "iza maske internacionalizma skrivala se ravnodušnost prema svim vrstama samospoznaje, tako i prema Mađarskoj. Nije smjelo biti pitanja što znači ako je netko Rumunj, Slovak, Srbin, Nijemac, Hrvat i ni to da je Mađar iz Mađarske", i do tzv. "mađarizacije" je došlo upravo zbog "ravnodušnosti" režima. Ni pripadnici većinske nacije nisu bili na čisto sa sobom (Fehér 1993:37), što je onda vodilo u krizu narodnog a i moralnog identiteta cijeloga mađarskog društva, a što poslije u totalitarnom sustavu rezultira naglim liberalnim tendencijama i potrazi za identitetom, zajednicom, pa povratku starijim identitetima, čemu se danas svjedoči. Nalazi su u skladu s mišljenjem Jadranke Grbić: članovi "bunjevačke zajednice su vezani različitim kulturama i motivima" (Grbić 1994:40) i Barthovim saznanjima kako su identiteti u stalnoj interakciji s drugima (Barth 1969), s drugim kulturnim zajednicama, u stalnoj fluktuaciji. Vidi se da je identitet višedimenzionalan, "dijaboličan", "fluidan", "ambivalentan", "promjenjiv" i da se s "identitetima pregovara za svoga života" (Bauman 2009, prema Grbić 1994:53), kako u prelazima u "južnoslavenstvo", pa u "hrvatstvo", ali i u prelazima među narodnostima 'od Mađara ili Švabe postane Bunjevac', 'od Bunjevca Mađar'. Vidi se kako je etnicitet "neodređen aspekt društvenoga života kojim se može manipulirati, različitoga je značenja u različitim situacijama te najčešće od samih sudionika ovisi kakav će on biti" (Grbić Jakopović 2014:57), te, kako Eriksen tvrdi, svaki pojedinac ima više različitih identiteta i statusa, stoga pripada različitim zajednicama (Eriksen 2007, prema Grbić 1994:49). 
Na srednju generaciju Bunjevaca povijesni kontekst djeluje poput instrumentalističke teorije na etnicitet, dakle da je etnicitet samo socijalni konstrukt a grupne granice nisu primordijalne, urođene, nego umjetno stvorene i održavane radi pragmatične koristi ili kao oruđe za pridobivanje kolektivnih uspjeha i neke financijske koristi. No, iz perspektive psihološke znanosti znamo kako se identiteti stvaraju u dijadama dakle počinju u uskoj obitelji, to je razlog zbog čega se ljudi drže svojih viđenja koja su naučili kao članovi dijada zatim grupe i kolektiva. Taj je najraniji utjecaj i najupečatljiviji u identitetima. Moja saznanja potvrđuju Patakijeve misli: "strategija kontrole informacije totalitarne države uzrokuje tipične poremećaje pamćenja u 'self slici' pojedinca i uređivanje njegove životne priče", što onda uzrokuje rascjepkanost, heterogenost u etničkim identitetima. lako neki autori govore o kontekstualnom karakteru identiteta, čemu smo i u ovoj građi svjedoci, i što Krappmann (1975) bilježi izrazom "balansirajući identitet", ovaj povijesni i politički kontekst srednje a i starije generacije uzrokovao je značajne promjene u odnosu na život prijašnjih generacija, a koje su zahtijevale velike odluke u životu pojedinaca, pa i cijele zajednice Bunjevaca. Ti su događaji uzrokovali rast složenosti identiteta, a nerijetko je došlo do "odbijanja" ili "devalviranja"4 nekih elemenata identiteta (Pataki 2001:400). Ove emotivne odluke najčešće su se vratile nakon promjene sustava ili kasnije, o čemu svjedoči sve veći broj Hrvata u popisima stanovništva, fenomen koji se viđa kod sljedeće, najmlađe generacije. Sve u svemu, Bunjevcima je korist i interes (Conversi 2007, prema Grbić Jakopović 2014:54) predstavljati se pod "hrvatskim" etnonimom da bi stekli sredstvo za ostvarenje svojih kulturnih ciljeva kao manjina, što potvrđuje instrumentalističke teorije o etničkom pripadanju kao odluci vođenoj razumom, a koja ima lojalni karakter bez emocija. Etnonim "Bunjevci" i sve što je u asocijaciji s tim etnonimom doživljavaju prirodno, urođeno, emocionalno, a ti segmenti potvrđuju primordijalističke teorije identiteta.

\section{Mlada generacija, rođeni poslije 1975. godine}

Kazivači koji ne govore bunjevački ili hrvatski navode kako im je žao što im roditelji nisu predali jezik, niti su pokušavali, pa to neki od njih pokušavaju nadoknaditi, npr. online hrvatskim tečajevima, aktivnim sudjelovanjem u bunjevačkoj zajednici. Oni mladi koji žive u Budimpešti ili Pečuhu najčešće su pohađali hrvatske obrazovne centre i njeguju hrvatski jezik. Vidljivo je da je predaja bunjevačke baštine ovoj generaciji više ovisila o bakama i djedovima, dakle o najstarijoj generaciji a ne o roditeljima. Primjećuje se jaka privrženost svom selu, zavičaju i bačkoj regiji i povremeno "idealiziranje" seoskog i bunjevačkog načina života u Bačkoj, "zamišljanje" (Anderson 1990). Jedan Budimpeštanac Bunjevac

\footnotetext{
${ }^{4}$ Devalviranje po Patakiju znači da će zadržati u svojoj biografiji, ali mu mijenja značenje i važnost u svom vrijednosnom sustavu.
} 
kaže da, kad bi postojala autocesta između Budimpešte i Baje, on bi se preselio u Bikić i svakodnevno bi dolazio na posao u Budimpeštu (oko 175 km), jer "ne želi da prodaju seosku kuću od dide", izražavajući jake emocije prema zavičaju predaka, dok mu se u pozadini majka smije. Mladi bi kazivači rado izabrali za bračnog partnera Bunjevca/ Bunjevku, no nije to jedini i glavni kriterij. U Budimpešti je samo jedan plesni ansambl, osnovan 1996. godine, "Hrvatska izvorna grupa, Budimpešta" ${ }^{5}$ za odrasle Hrvate u Mađarskoj, gdje su od 22 osobe samo četiri podrijetlom Bunjevci. U okviru hrvatskog vrtića, osnovne škole, gimnazije i đačkog doma, danas postoji i glumačka sekcija koju pohađaju učenici hrvatske škole (dakle djeca svih hrvatskih manjina u Mađarskoj a i Mađari) koji u okviru školskog programa HOŠıG-a, ${ }^{6}$ redovito posjećuju matičnu zemlju, Hrvatsku.

\section{Analiza trećeg dijela}

Kod mladih se potvrđuju Patakijeve misli, dakle devalviranje etničkog identiteta kod srednje generacije nije završni proces - u skladu s fenomenom američkoga melting pota. Patakijevim riječima: "među svim identitetima, statusima i ulogama, ipak etnonacionalni i lokalni sadržaji su zato toliko moćni jer imaju duboke korijene u pretežno emocionalnim, neverbalizirajućim iskustvima i iskustvima najranijeg razvoja" (Pataki 2001:124) što onda potvrđuje važnost primordijalističkih teorija u istraživanjima etničkog identiteta.

\section{ANALIZA GRAĐE}

"Etnički identiteti su kao vrsta predmodernih identiteta, predstavljaju predmet velikih polemika jer se doživljavaju gotovo kao predpolitički identiteti nastali prije bilo kakve političke organizacije društva, a predmoderni politički ustroj doživljava se prvenstveno kao ustroj utemeljen na staleškoj pripadnosti" (Skenderović 2014:79), i zbog čega je fascinantan fenomen kako bunjevačka zajednica u Mađarskoj u svom prirodnom obliku s nepisanim pravilima preko više od 350 godina uspijeva držati homogenim svoj etnicitet i kulturu bez sustava institucija koji bi čuvao njihova etnička i kulturna prava, te kako toj stoljetnoj homogenoj zajednici posljednji udarac daje staljinistički komunistički režim. Posljednji kazivači homogene bunjevačke kulture i etniciteta najstariji su kazivači ovog istraživanja, za vrijeme pisanja ovog rada troje in je umrlo. Spontana i prirodna javna mjesta druženja zamjenjuju planirana druženja na tzv. nemjestima (Čapo i Gulin Zrnić

\footnotetext{
${ }^{5}$ www.horvathagyomanyorzo.hu

${ }^{6}$ Hrvatska osnovna škola, gimnazija i đački dom, Budapest. www.hosig.hu (pristup 7. 5. 2019).
} 
2011) i više ne pod etnonimom "Bunjevci" jer u svakodnevnoj interakciji i komunikaciji u Mađarskoj riječ "Bunjevac" polako gubi relevantnost i privlačnost. U javnom i službenom predstavljanju bunjevački se etnonim pretvorio u hrvatski. Udruživanja Bunjevaca u skladu s globalizacijskim, liberalizacijskim i migracijskim procesima i na online društvenim mrežama kod posljednjih dviju generacija poprimaju mnogo heterogeniji karakter nego kod bilo koje prijašnje generacije posljednjih 300 godina. Udruživanje Bunjevaca uvelike se događa oko plesa i glazbe, a najčešće ne razumiju što pjevaju ili plešu. Dakle, na današnju generaciju Bunjevaca moramo gledati iz perspektive britanskog marksista i povjesničara Erica Hobsbawma koji utvrđuje da korištenje riječi "zajednica" nikada nije bio toliko "ravnodušan" i "besmislen" pojam kao u naše doba: u vrijeme kada je jako teško pronaći "zajednice" u sociološkom smislu te riječi (Hobsbawm 1991). Zato danas identitet ima ulogu zamijeniti zajednicu zbog čega će imati veliku pozornost i uzrokovati veliku strastvenost, što vidimo u raspravama između aktivista izvornih bunjevačkih zajednica i aktivista trenda "balkan-kulture", ${ }^{7}$ ili kako sam ih nazvala "aktivisti 7/8 ritmičkih plesova". Naila Ceribašić ističe važnost zajedničkog djelovanja i interesa naspram etničkog identiteta: "uz etničku postoje i druge dimenzije identiteta, višestruki osjećaji pripadnosti i raznolike akcije koje ih potvrđuju i stvaraju, pa ni etnička, u odnosu s tim drugim dimenzijama, nikad nije jednoznačna. Sukladno tomu, ni zajednice nisu unaprijed definirane, već su i rezultatom ljudske akcije, slobodnog i dobrovoljnog, privremenijeg ili trajnijeg, djelomičnijeg ili predanijeg udruživanja većeg ili manjeg broja ljudi oko nekog zajedničkog osjećaja, interesa, uvjerenja i/ ili ljubavi." (Ceribašić 2005:31), što potvrđuje mišljenje kazivača koji smatraju da nije bitna heterogenost, važna je kohezijska sila manjinske zajednice za opstanak. Naime, posljednje tri uzastopne generacije ne mogu prenijeti svoje naslijeđene obrasce identiteta u nepromijenjenom obliku, kako su to prije stotinama godina uspijevale. Razlog tomu jest nestanak neposrednog kontakta sa zavičajem, širom obitelji i poljodjelskog načina života, u čemu je bunjevaštvo imalo legitimitet. Neposredno živo iskustvo u zajednici prvo je zamijenio radio i tiskano slovo, kasnije i ostali mediji: televizija, internet, Facebook, preko čega je više tisuća ljudi postalo povezano i stvaralo "izmišljene zajednice" (Anderson 1990:56), i počinju u tim kategorijama razmišljati, postavljati zamišljene norme i po tome prosuđivati. Dolazi do neprirodnih tendencija zbog udaljavanja od neposrednoga živog iskustva bunjevačke obitelji, zajednice i nastaju sve heterogenije varijante $u$ formiranju zajednica. Liberalizacijski procesi globalno diktiraju iluzionistički trend slobodnog izbora. U skladu s time danas je razlika između biološki urođenih i kulturno stečenih elemenata identiteta sve manje oštra. Dok se kod prve generacije urođeni i kulturni elementi identiteta isprepliću (Bunjevac je taj čiji su roditelji čistokrvni Bunjevci), danas

\footnotetext{
${ }^{7}$ Facebook stranice: @BalkanEventsHungary, @YuParty.
} 
su ti elementi udaljeni jedan od drugoga: biološki faktori više ne određuju subjektivni doživljaj identiteta - bar naizgled! Individualizam jača naspram kolektivističkog načina razmišljanja i rezultat toga jest otuđenje, osamostaljenje u društvu. Prema Baumanovim riječima, "kategorije identiteta postupno odvajaju svoje prirodne, gotove i fiksirane temelje" (Bauman 2001), identiteti izlaze iz okvira partikularnih vremena i prostora i odvajaju se od običaja koji su vezani uz njih (Feischmidt 1997:13), počinje "hibridizacija" i nastaju hibridni identiteti postmodernog subjekta (Hall 2003) koji se onda očituju u pojavi identiteta koji nisu izvorni dijelovi bunjevačke zajednice: mađarski elementi, južnoslavenski elementi, hrvatski elementi itd. U skladu s tim, načini i kriteriji pripadanja zajednici postaju liberalniji, subjektivniji, a "simboličke granice zajednice" (Cohen 1985) prozirnije. U tom društvenom kontekstu bunjevačka zajednica više se ne sastoji nužno od Bunjevaca, zato je glavna zadaća "Bunjevaca" stvarati zajednicu, povezati otuđene ljude s temeljnim ljudskim potrebama: u kolektiv sa zamišljanjem nekadašnjeg kolektiva i zadovoljiti psihološku potrebu za homogenošću i isticanjem. Riječima pionira kulturalne psihologije Georgea De Vosa (De Vos 2006), "biti jedinstven i poseban”, što dolazi od osjećaja razlikovati sebe od drugih, dakle od osnovne potrebe čovjeka za identificiranjem, distanciranjem (individualizacijom) u procesu socijalizacije. Prema tome, posljednji nositelji čvrstoga homogenog bunjevačkog etničkog identiteta jesu najstariji kazivači. Oni su bila posljednja generacija čija se socijalizacija ostvarila preko jasnih simboličnih granica temeljem neposrednih fizičkih kontakata i iskustva (dakle uz jako malo utjecaja tiska i medija) i skoro pa isključivo usmene predaje pravila održavanja kontinuiteta identiteta. Mladi Bunjevci, preko institucionaliziranih oblika njegovanja bunjevačkog identiteta dobivat će jedan novi identitet, a to je "hrvatstvo" jer se njihova enkulturacija i socijalizacija događa kroz hrvatsko školstvo pod krilom hrvatske države. U skladu s Le Bonovom teorijom (Le Bon 1894, 2004) kako "u karakteru naroda leži mogućnost za opstanak a ne u intelektualnosti i civilizaciji", vidimo kako homogenost, kohezijska sila i preživljavanje bunjevačke zajednice nikad nije ovisilo o intelektualnoj eliti nego upravo suprotno - o karakteru prosječnih i manje civiliziranih Bunjevaca koji ovih godina izumiru.

\section{ZAKLJUČAK}

Kroz tri različite živuće generacije u povijesnom kontekstu vidi se kako se etnička simbolična granica mijenjala od strogih nepisanih pravila bunjevačke zajednice s homogenim tendencijama, kroz ideologije različitih "izama", negiranja etničkog i bilo kakvog identiteta do liberalnih, prozirnih granica u kojima se javljaju ne samo heterogeni nego i hibridni identiteti. Hibridnost i heterogenost ostvaruju se kroz različita druženja bunjevačke zajednice. Sredinom prošlog stoljeća spontana, prirodna udruživanja 
na osnovi stvarnoga fizičkog kontakta oblikovala su homogene identitete, pa rastom fizičke mobilnosti, migracija, širenjem tiska, radija, televizije, interneta, pa do društvenih mreža kao što je Facebook, bunjevačka je zajednice sve "izmišljenija", idealiziranija, a kontakti među njihovim članovima ostvaruju se sve više u organiziranim, nespontanim udruženjima, ali najviše za plesnih i glazbenih priredbi. Priredbe zajednice poprimile su sve prozirnije "granice". Do prozirnosti je došlo djelomično u strahu uzrokovanom povijesnim kontekstom, te odlukama vođenim idejom "manjeg otpora" i miješanjem različitih elemenata različitih etničkih i kulturnih grupa. Hibridni i složeni bunjevački identitet do danas ima tendenciju odupiranja a i očuvanja heterogenost te kako očuvati i oduprijeti se homogeniziranju bunjevačkog identiteta. Odupiranje trendu "7/8 plesnih formi" oblik je razlikovanja sebe od naroda bliskih sebi, "Balkanaca", "Južnoslavenstva", dakle tu se vide tendencije čuvanja homogenosti i odupiranje heterogenosti zajednice (homogenizacijske tendencije), a s druge se strane događa i odupiranje homogenizacijskim tendencijama u većinsku hrvatsku naciju naglašavanjem heterogenosti (heterogenizacijske tendencije), npr. privrženost mađarskom jeziku i državi. Kod mlade generacije javlja se buđenje interesa prema etničkom identitetu i unatoč prisutnosti različitih kulturnih sredina, to ne dovodi u pitanje naslijeđenu bunjevačku baštinu, njegovu vrijednost i legitimitet koji sve više dolazi u dodir s matičnom zemljom Hrvatskom i suvremenim "hrvatstvom".

\section{LITERATURA}

ANDERSON, Benedict. 1990. Nacija: zamišljena zajednica. Zagreb: Školska knjiga.

BARA, Mario. 2012. "Ekohistorijski pristup migracijama Bunjevaca". Godišnjak za znanstvena istraživanja, vol. 4:11-31.

http://www.zkvh.org.rs/index.php/dokumenti/send/16-2012/955-bara2012r

BARTH, Fredrik, ur. 1969. Ethnic Gropus and Boundaries: The Social Organization of Cultural Difference. Boston: Little Brown \& Co.

BAUMAN, Zygmunt. 2001. Identitás és globalizáció. Magyar Lettre International, vol. 42. https://epa.oszk.hu/00000/00012/00026/bauman.htm

BAUMAN, Zygmunt. 2009. Identitet - razgovori s Benedettom Vecchijem. Zagreb: Pelagio. BOURDIEU, Pierre. 1984. Distinction: A Social Critique of the Judgment of Taste. London: Routledge.

CERIBAŠIĆ, Naila. 2005. "Krajolici nacionalnih manjina na manifestacijama kulturnog amaterizma u Hrvatskoj". Narodna umjetnost, vol. 42/2:9-38.

https://hrcak.srce.hr/2932

CHARMAZ, Kathy. 2011. Constructing Grounded Theory. A Practical Guide Through Qualitative Analysis. Los Angeles: Sage.

COHEN, Anthony P. 1985. The Symbolic Construction of Community. London: Tavistock. 
CONVERSI, Daniele. 2007. "Mapping the Field: Theories of Nationalism and the

Ethnosymbolic Approach". U Nationalism and Ethnosymbolism. History, Culture and Ethnicity in the Formation of Nations, ur. Athena S. Leoussi i Steven Grosby. Edinburgh: Edinburgh University Press, 15-30.

CSEPELI, György. 2002. Szociálpszichológia. Budapest: Osiris Kiadó.

ČAPO, Jasna i Valentina GULIN ZRNIĆ, ur. 2011. Mjesto, nemjesto. Interdisciplinarna promišljanja prostora i kulture. Zagreb: Institut za etnologiju i folkloristiku.

ČERNELIĆ, Milana. 2005. "Pristupi istraživanju bunjevačkih identiteta". Studia ethnologica Croatica, vol. 17:25-49. https://hrcak.srce.hr/4945

DE CERTEAU, Michel. 2003. Invencija svakodnevnice. Zagreb: Naklada MD.

DE VOS, George A. 2006. "Introduction: Ethnic Pluralism: Conflict and Accomodation. The Roal of Ethnicity in Social History". U Ethnic Identity. Problems and Prospects for The Twenty-First Century, 4. izd., ur. Lola Romanucci-Ross, George A. De Vos i Takeyuki Tsuda. Lanham: Altamira Press, 1-35.

EMERSON, Robert M., Rachel I. FRETZ i Linda L. SHAW. 1995. Writing Ethnographic Fieldnotes. Chicago: University of Chicago Press.

ERIKSEN, Thomas Hylland. 2007. "Complexity in social and cultural integration: some analytiyal dimensions". Ethnic and Racial Studies, vol. 30/6:1055-1069. DOI: https://doi.org/10.1080/01419870701599481

FEHÉR, István. 1993. Az utolsó percben. Magyarország nemzetiségei 1945-1990. Budapest: Kossuth Könyvikadó.

FEISCHMIDT, Margit, ur. 1997. Multikulturalizmus: kultúra, identitás és politika új diskurzusa. Budapest: Osiris. https://kisebbsegkutato.tk.mta.hu/uploads/files/olvasoszoba/ multikulturalizmus/Feischmidt\%20Margit\%20-\%20Multikulturalizmus.pdf (pristup 1. 9. 2019.).

GRBIĆ JAKOPOVIĆ, Jadranka. 1994. Identitet, jezik i razvoj. Zagreb: Institut za etnologiju i folkloristiku.

GRBIĆ JAKOPOVIĆ, Jadranka. 2014. Multipliciranje zavičaja i domovina. Hrvatska dijaspora: kronologija, destinacije i identitet. Zagreb: Filozofski fakultet u Zagrebu, Odsjek za etnologiju i kulturnu antropologiju.

HALL, Stuart. 2003. "Introduction". U Representation: cultural representations and signifying practices, ur. Stuart Hall. London: Sage: 1-13.

HOBSBAWM, Eric J. 1991. Etnikai identitás és nacionalizmus. Predavanje. Chicago, 23. 11. 1991. http://adatbank.transindex.ro/html/cim_pdf719.pdf (pristup 25. 7. 2019.)

KRAPPMANN, Lothar. 1975. Soziologische Dimensionen der Identität: strukturelle Bedingungen für die Teilnahme an Interaktionsprozessen. Stuttgart: Klett.

LÁSZTITY, S. Lyubomir. 1987. "A magyarországi délszlávok negyven éve". U Nemzetinemzetiségi tudat: Szigetvári Konferenciák, 1984-1986, ur. Imre Polányi. Pécs, 202-205.

LE BON, Gustave. 1894. Les lois psychologiques de l'évolution des peuples. Paris: Félix Alcan. 
LE BON, Gustave, ur. 2004. Psihologija naroda, gomila, revolucija. Zagreb: Golden marketing - Tehnička knjiga.

LUKAČ, Stjepan. 1999. Relacije tišine. Budimpešta: Budimpeštanska hrvatska samouprava, Hrvatski ansambl Luč.

MARCUS, George E. 1995. "Ethnography in/of the World System: The Emergence of Multi-Sited Ethnography". Annual Review of Anthropology, vol. 24:95-117. DOI: https://doi.org/10.1146/annurev.an.24.100195.000523

PATAKI, Ferenc. 2001. Élettörténet és identitás. Budapest: Osiris Kiadó.

SKENDEROVIĆ, Robert. 2014. "Bunjevački i dalmatinski identitet u ugarskom Podunavlju u razdoblju od 17. do 19. stoljeća". U Bunjevci u vremenskom i prostornom kontekstu, ur. Milana Černelić et al. Zagreb: Filozofski fakultet Sveučilišta u Zagrebu, Odsjek za etnologiju i kulturnu antropologiju - Subotica: Zavod za kulturu vojvođanskih Hrvata, 273-282.

ŠARIĆ, Marko. 2014. "Seoba Bunjevaca u Podunavlje 1607. godine u svjetlu osmanske politike prisilnog preseljenja stanovništva (Sürgün)". U Bunjevci u vremenskom i prostornom kontekstu, ur. Milana Černelić et al. Zagreb: Filozofski fakultet Sveučilišta u Zagrebu, Odsjek za etnologiju i kulturnu antropologiju - Subotica: Zavod za kulturu vojvođanskih Hrvata, 45-78 .

ŠOKČEVIĆ, Dinko. 2014. "Slika Bunjevaca u djelu Dr. Jenőa Meznericha: Bunyeváco (Bunjevci) iz 1938". U Bunjevci u vremenskom i prostornom kontekstu, ur. Milana Černelić et al. Zagreb: Filozofski fakultet Sveučilišta u Zagrebu, Odsjek za etnologiju i kulturnu antropologiju - Subotica: Zavod za kulturu vojvođanskih Hrvata, 89-95.

TÓTH, Ágnes. 1989. "Telepítések Csonka Bács-Bodrog Vármegyében 1945-1948".

Levéltári füzetek: (Bács-Kiskun megye), vol. 5:5-100. https://library.hungaricana. hu/hu/view/BKKM_Lf_05_Toth/?pg=0\&layout=s

IZVORI

Balkan Cultural Events Hungary. https://www.facebook.com/BalkanEvents Hungary/ (pristup 7. 5. 2019.)

Hrvatska izvorna grupa, Budapest. www.horvathagyomanyorzo.hu (pristup 7. 5. 2019.)

Hrvatska osnovna škola, gimnazija i đački dom, Budapest. www.hosig.hu (pristup 7. 5. 2019.)

Központi Statisztikai Hivatal. https://www.ksh.hu/docs/hun/xttp/idoszaki/nepsz 2011/nepsz_orsz_2011.pdf (pristup 7. 5. 2019.) YuParty. https://hr-hr.facebook.com/YuParty/ (pristup 7. 5. 2019.) 


\section{Bunyevácok Magyarországon: posztmodern heterogén identitások}

\section{Eszter Punczman}

A vizsgálat a Magyarországi Bácska területén élő, bunyevác- horvát lakosság körében végzett kvalitatív, etnológiai és kulturális antropológiai terepkutatáson alapul. A cél azon párhuzamos folyamatok bemutatása, ahogy a különböző bácskai bunyevác generációk etnikai identitás megélése változott a történelmi kontextus tükrében és közÖsségük szimbolikus határa átjárhatóvá vált, heterogén identitások kialakulásához vezetve. A vizsgálat a bunyevác közösség homogenizációs törekvéseknek, vagyis egy nációba való olvasztás, ellenállását is bemutatja. Tekintettel arra, hogy a bunyevác közösség kohézióját többé nem a bunyevác-horvát nyelv adja, tehát, etnikai identitás tudat megléte nem nyelvhez kötött, ezért a hangsúlyt a magukat bunyevácoknak tartó egyének közötti "közös" jellemzőkre helyezem, melyek hasonlóvá teszi őket, vagyis képesek közösséggé formálni azok tagjait.

Kulcsszavak: bunyevácok, magyarországi horvátok, közösség, homogén nemzet, etnikai identitás, kisebbségek

\section{Bunjevci in Hungary: Postmodern Heterogeneous Identities}

\section{Eszter Punczman}

This study presents an ethnological and cultural anthropological fieldwork which was carried out among Bunjevci in the Hungarian part of Bačka region. The aim of this paper is to demonstrate the formation of the transparent and symbolic boundaries of the Bunjevci community and the emergence of heterogeneous identities in the historical context through three generations while creating Bunjevci identities. Consequently, this study shows how the members of the Bunjevci community resist to homogenise into the majority group and nations; while, on the other hand, the research determines the heterogeneous character of the Bunjevci community in Hungary. The cohesion force of the community is not the Bunjevac speech, which states that the ethnical identity is not directly connected to the language. Therefore, it is essential to devote attention to the similarities and common features among those who consider themselves Bunjevci. 
Keywords: Bunjevci, Croatian minority group in Hungary, heterogeneous culture, homogeneous nation, multiple identities

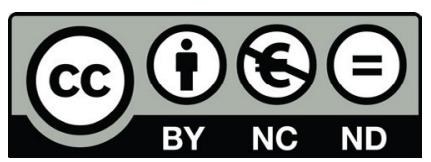

Articles published in this journal are Open Access and can be distributed under the terms and conditions of the Creative Commons license Attribution-NonCommercial-NoDerivatives 4.0 (http://creativecommons.org/licenses/by-nc-nd/4.0/) 